\title{
Placental Growth and Glycogen Metabolism in Streptozotocin Diabetic Rats
}

\author{
IRA H. GEWOLB ${ }^{(36)}$ CAROLYN BARRETT, AND JOSEPH B. WARSHAW ${ }^{(37)}$ \\ Departments of Pediatrics, Albert Einstein College of Medicine, Bronx, New York and the University of Texas Health \\ Science Center at Dallas, Dallas, Texas, USA
}

Summary

Placental glycogen metabolism was investigated in rat pregnancies complicated by streptozotocin-induced diabetes mellitus. Both diabetic and control placentas had increasing glycogen concentration from day 14 to day 16 , after which glycogen concentration declined rapidly. The diabetic placentas had significantly elevated glycogen concentration when compared to controls from day 16 through term (day 22). Near term, when control glycogen content fell close to zero, the diabetic placentas still had appreciable glycogen levels.

Total phosphorylase activity in the diabetic placentas was significantly higher than control values from day 16-22. Phosphorylase $A$ activity, however, was lower in the diabetic placentas late in gestation, corresponding to the increased glycogen concentration seen at that time. Diabetic placentas had increased total synthase activity on the final 3 days of gestation, although synthase A activity was lower than corresponding control values.

The placentas in this model are markedly increased in size late in gestation. No difference in protein concentration or protein/ DNA ratio was noted. Total DNA content per placenta was significantly increased in the diabetic placentas after day 16 when compared to controls. Placental DNA in the diabetics continued to increase until day 18-19 of gestation, whereas DNA content in control placentas remained constant after day 16 . Thus, the diabetic placentas apparently continue the process of DNA replication after DNA synthesis is complete in the controls.

Normal gestation is characterized by an early peak in placental glycogen content, followed by a progressive depletion as term approaches $(4,26,33)$. Both human $(9,13,17)$ and animal $(1,16$, 30) pregnancies complicated by diabetes mellitus have markedly increased placental glycogen stores.

The two rate-limiting enzymes regulating glycogen synthesis and breakdown are glycogen synthase (EC 2.4.1.11) and glycogen phosphorylase (EC 2.4.1.1), respectively. Prior studies have noted that placental glycogen synthase decreases and phosphorylase increases with advancing gestational age, consistent with the decline in placental glycogen concentration late in gestation (10) Nevertheless, previous investigations of placentas from diabetic pregnancies found a seemingly paradoxical increase in phosphorylase and a decrease in the active synthase fraction in spite of increased glycogen content $(1,9)$.

This pattern of a rise in glycogen concentration followed by a fall late in pregnancy is also characteristic of the normal fetal lung. Using the streptozotocin diabetic rat, we have demonstrated that glycogen concentration in the lungs of fetuses of diabetic pregnancies follows a normal pattern of accumulation for the first 20 days of gestation, after which there is a delay in the normal process of degradation (12). We also found a significant decrease in the activity of the glycogenolytic enzyme phosphorylase A during the final 3 days of gestation, at precisely that time that changes in pulmonary glycogen concentration became evident. It thus appeared, at least in the lung, that differences in glycogen concentration could be explained by changes in the activity of phosphorylase A.
The present study was designed to construct a developmental profile of glycogen accumulation in the streptozotocin diabetic rat. In view of the correlation between pulmonary glycogen degradation and phosphorylase A activity in fetuses of diabetic pregnancies, a similar attempt was made to define the enzyme profile of glycogen metabolism in the diabetic placentas. The placentomegaly noted in this model $(1,12,30)$ also prompted us to investigate whether this increase in size was the result of hyperplasia, cellular hypertrophy, or both.

\section{MATERIALS AND METHODS}

Non-pregnant adult female Sprague-Dawley rats (Charles River Breeding Laboratories, Cambridge, MA) were injected with 40 $\mathrm{mg} / \mathrm{kg}$ of streptozotocin (courtesy of Upjohn Co., Kalamazoo, MI), a specific pancreatic beta-cell cytotoxin, dissolved in $5 \mathrm{mM}$ sodium citrate buffer, $\mathrm{pH}$ 4.5. Control females received an equivalent amount of buffer solution. Five to seven days after injection the females were caged overnight with adult male rats. Day $l$ of pregnancy was considered to be the morning that a cervical swab positive for sperm was obtained.

Animals were killed by decapitation on days 14-22 (term). The uterus was rapidly removed and placed on ice within $15 \mathrm{sec}$ of removal. Six placentas were dissected free of cord, membranes, and clots and were immediately frozen in glass tubes placed in an ethanol/dry ice bath. Placentas were then stored at $-70^{\circ} \mathrm{C}$ until analyzed. Remaining placentas were set aside for weight determination.

Glycogen concentration was measured using a previously described modification (25) of the method of Lowry and Passoneau (24). Protein content was assayed by the method of Lowry $e t$ al. (23). The method of Hill and Whatley (20) was utilized for DNA determination.

Glycogen synthase activity was determined using a modification of the method of Eisen et al., (7) optimized for placental tissue. Whole placenta was homogenized $(1: 10 \mathrm{w} / \mathrm{v})$ in a buffer consisting of $20 \mathrm{mM}$ glycylglycine, pH $8,100 \mathrm{mM} \mathrm{NaF}, 3 \mathrm{mM}$ dithiothreitol, and $5 \mathrm{mM}$ EDTA. For synthase A (active) determination, a 25 $\mu \mathrm{l}$ aliquot (approximately $250 \mu \mathrm{g}$ of protein) was added to a $25 \mu \mathrm{l}$ solution consisting of $10 \mathrm{mM}$ UDP- $\left[{ }^{14} \mathrm{C}\right]$-glucose (specific activity $0.02 \mathrm{mCi} / \mathrm{mM}), 0.7 \mathrm{mg} / \mathrm{ml}$ glycogen, and $100 \mathrm{mM}$ Tris $\mathrm{HCl}$ buffer, $\mathrm{pH} 8$, and allowed to incubate for exactly five minutes in a $30^{\circ} \mathrm{C}$ water bath. At the end of the incubation period, $30 \mu \mathrm{l}$ of the mixture was spotted on a \#31, Whatman filter paper disc. The discs were immediately placed in cold ethanol. After 4 washes in cold ethanol lasting $90 \mathrm{~min}$ a final wash with acetone for $5 \mathrm{~min}$ was performed. The dry discs were then placed in $10 \mathrm{ml}$ of Econofluor and counted on a Beckman scintillation counter to quantify the incorporation of UDP- $\left[{ }^{14} \mathrm{C}\right]$-glucose into glycogen. For the determination of total $(A+B)$ glycogen synthase, the assay solution also contained $10 \mathrm{mM}$ glucose-6-phosphate. Under the above conditions the reaction rate was linear for at least $3 \mathrm{~min}$ with up to $400 \mu \mathrm{g}$ of protein.

Glycogen phosphorylase was measured in the direction of glycogen degradation using a modification of previously described assay procedures $(12,25)$, optimized for placental tissue. Placentas were homogenized in 10 volumes $(w / v)$ of a solution containing 
$100 \mathrm{mM} \mathrm{NaF}$ and $50 \mathrm{mM}$ Tris-succinate, $\mathrm{pH}$ 6.9. For determination of phosphorylase A, a 15-min preincubation with 5'-adenylic acid deaminase (EC 3.5.4.6; Sigma Chem. Co., St. Louis, Mo.) and $50 \mu \mathrm{l}$ per $\mathrm{ml}$ of homogenate, was carried out in a $30^{\circ} \mathrm{C}$ water bath. This step was needed to remove any endogenous $5^{\prime}$-AMP, a potent stimulator of phosphorylase B. Enzyme activity was then assayed by adding $15 \mu \mathrm{l}$ (approximately $150 \mu \mathrm{g}$ of protein) of the tissue homogenate to an assay solution consisting of $50 \mathrm{mM}$ imidazole buffer, $30 \mathrm{mM} \mathrm{KH} \mathrm{PO}_{4}, 0.2 \mathrm{mM}$ EDTA, $0.7 \mathrm{mg} / \mathrm{ml}$ glycogen, 0.9 unit/ml glucose-6-phosphate dehydrogenase, 0.45 unit/ml phosphoglucomutase, and $0.4 \mathrm{mM}$ caffeine at a final $\mathrm{pH}$ of 6.9. The rate of NADPH generation was measured fluorometrically on a Perkin-Elmer fluorimeter (Perkin-Elmer Co., Norwalk, CT). For measurement of total $(A+B)$ phosphorylase, the homogenate was preincubated for $30 \mathrm{~min}$ in a $30^{\circ} \mathrm{C}$ water bath with a solution of $60 \mathrm{mM}$ ATP and $200 \mathrm{mM} \mathrm{MgCl}_{2}, \mathrm{pH} 7(100$ $\mu \mathrm{l} / \mathrm{ml}$ homogenate). Activity was then assayed as for phosphorylase A except that $1.5 \mathrm{mM}$ 5'AMP was added to the reaction medium in place of the caffeine. Activity was linear for at least 40 min and for at least $25 \mu \mathrm{g}$ of protein. Chemicals were obtained from Sigma Chemical Co. (St. Louis, MO). Radioactive material was obtained from New England Nuclear (Boston, MA).

All statistical calculations used the Student's $t$ test. $\mathrm{P}<0.01$ was considered statistically significant. All assays were performed in triplicate. Interassay and intra-assay variability was on the order of $10 \%$.

\section{RESULTS}

Streptozotocin injection resulted in overt maternal hyperglycemia, with a mean maternal plasma glucose concentration at time of killing equal to $498 \pm 11$ (S.E.) $\mathrm{mg} / \mathrm{dl}$ versus $104 \pm 2 \mathrm{mg} / \mathrm{dl}$ for the controls. Maternal insulin levels were approximately $1 / 2$ of control values. Fetuses were also hyperglycemic, with plasma glucose concentrations of $355 \pm 10$ (S.E.) $\mathrm{mg} / \mathrm{dl}$ as opposed to 51 $\pm 4 \mathrm{mg} / \mathrm{dl}$ for controls; however, fetal hyperinsulinemia was not seen in this model: diabetic litters had mean insulin levels of 75 \pm 8 (S.E.) $\mu \mathrm{unit} / \mathrm{ml}$ compared to control values of $83 \pm 9 \mu \mathrm{unit} /$ $\mathrm{ml}$ (12). This is in agreement with the findings of previous investigators using this model $(8,12,15,27,31)$, in contrast to the findings of fetal hyperinsulinemia in the human infant of a diabetic pregnancy. The fetuses in this model were significantly smaller than age-matched controls from as early as the 14th day of gestation (Table 1).

Glycogen concentration in the diabetic and control placentas is shown in Figure 1. Both diabetic and control placentas had increasing glycogen concentration from day 14 to day 16 , after which glycogen concentration declined rapidly in both. Diabetic placentas had significantly elevated glycogen concentration from day 16-22 when compared to control values. Near term, when control glycogen concentrations fell close to zero, the diabetic placentas still had appreciable glycogen levels.

Glycogen phosphorylase exists in two interconvertible forms: "A," the active, phosphorylated form, and "B," the inactive form. Total $(A+B)$ glycogen phosphorylase activity in the diabetic placentas was significantly higher than control values from day 16 through term (Fig. 2), whereas phosphorylase A activity was lower

Table 1. Fetal weight ${ }^{1}$ (mg wet weight \pm S.E.)

\begin{tabular}{cccccc}
\hline Day & Control & $n^{2}$ & Diabetic & $n^{2}$ & $P$ \\
\hline 14 & $86 \pm 4$ & 7 & $58 \pm 7$ & 3 & $<0.005$ \\
16 & $329 \pm 11$ & 5 & $278 \pm 6$ & 3 & $<0.05$ \\
18 & $857 \pm 37$ & 3 & $678 \pm 23$ & 3 & $<0.05$ \\
19 & $1673 \pm 50$ & 4 & $1290 \pm 78$ & 4 & $<0.01$ \\
20 & $2372 \pm 77$ & 8 & $2031 \pm 145$ & 7 & $<0.05$ \\
21 & $3862 \pm 142$ & 8 & $3105 \pm 253$ & 9 & $<0.05$ \\
22 & $5655 \pm 132$ & 9 & $4220 \pm 316$ & 8 & $<0.001$ \\
\hline
\end{tabular}

${ }^{1}$ Results expressed as $\mathrm{mg}$ wet weight \pm S.E.

${ }^{2} n$, Number of litters, with 3-4 fetuses weighed per litter.

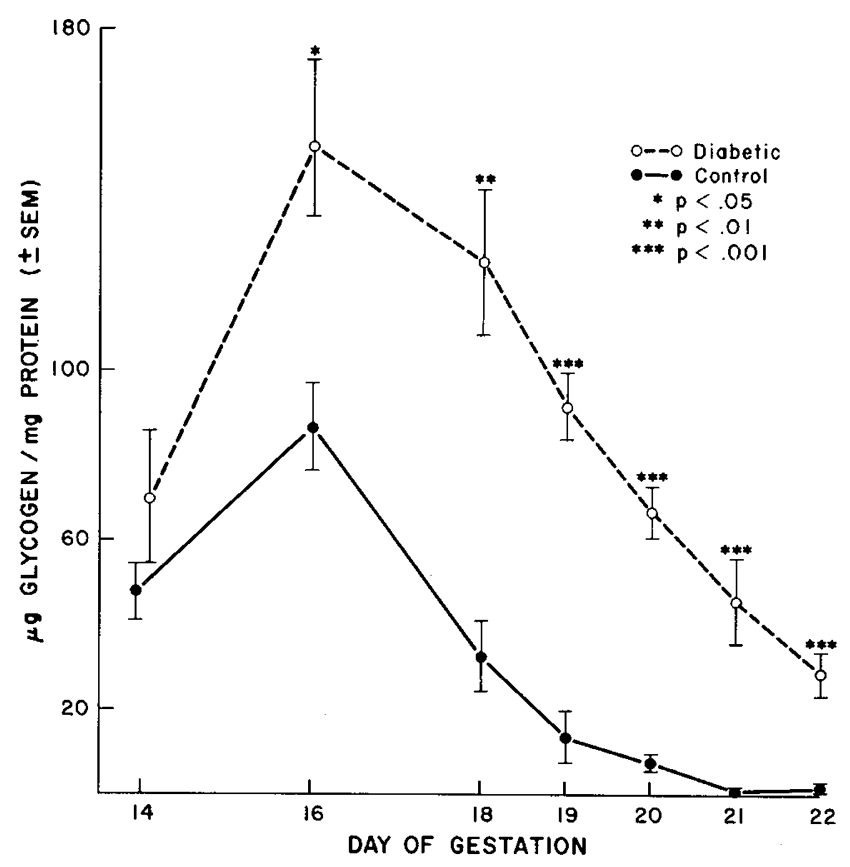

Fig. 1. Placental glycogen concentration. Each point in this and subsequent figures represents the mean \pm S.E. of placentas from an average of eight litters. Details of this and subsequent figures are given in the text.

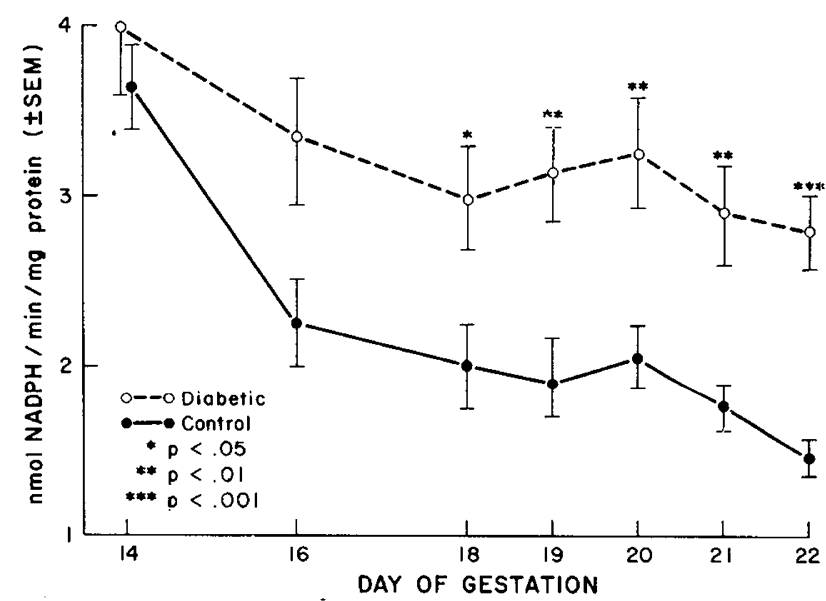

Fig. 2. Total $(A+B)$ placental glycogen phosphorylase activity.

in the diabetic placentas on days 20-21 (Fig. 3) corresponding to the increased glycogen concentration seen late in gestation; thus, the increase in total phosphorylase was entirely accounted for by the inactive " $B$ " fraction.

Glycogen synthase also exists in at least two interconvertible forms. The "A" form is independent of glucose-6-phosphate and is felt to be the active form in the liver. The " $B$ " form is dependent on the presence of glucose-6-phosphate and is thought to be inactive under physiologic conditions. Recently, intermediate forms of synthase have been found which may play a role in the regulation of glycogen synthesis $(22,29)$. Total glycogen synthase activity is shown on Figure 4. Diabetic placentas had increased total synthase activity on the final 3 days of gestation. But the independent " $A$ " fraction was lower in diabetics when compared to controls from day 19 through term (Fig. 5).

The placentas in this model were markedly increased in size from day 18 through term (Table 2). These differences were not accounted for by edema since the wet weight/dry weight ratio was the same from age-matched control and diabetic placentas.

The results of the DNA and protein determinations in control and diabetic placentas are shown in Table 3. From day 16-22 


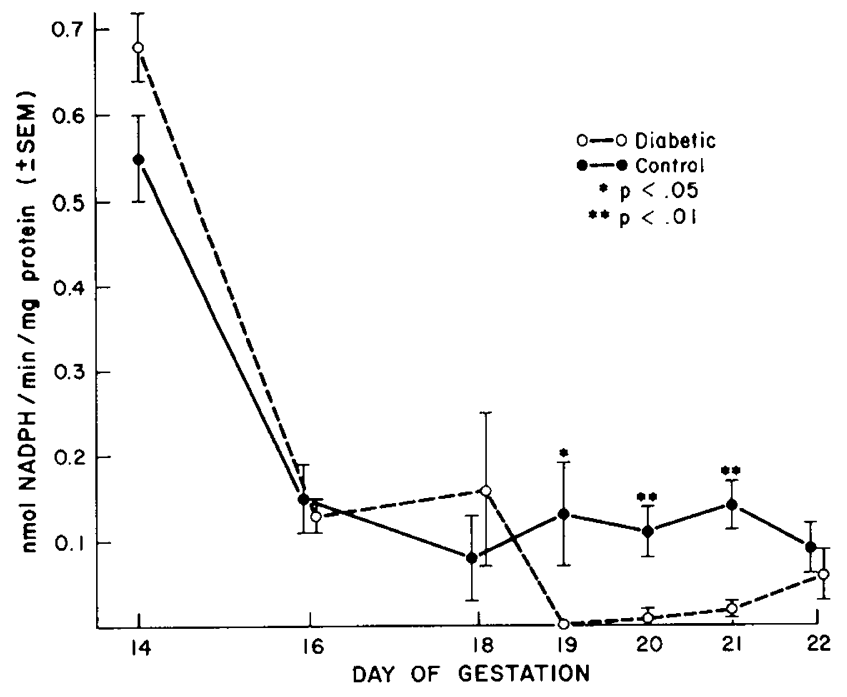

Fig. 3. Placental glycogen phosphorylase A activity.

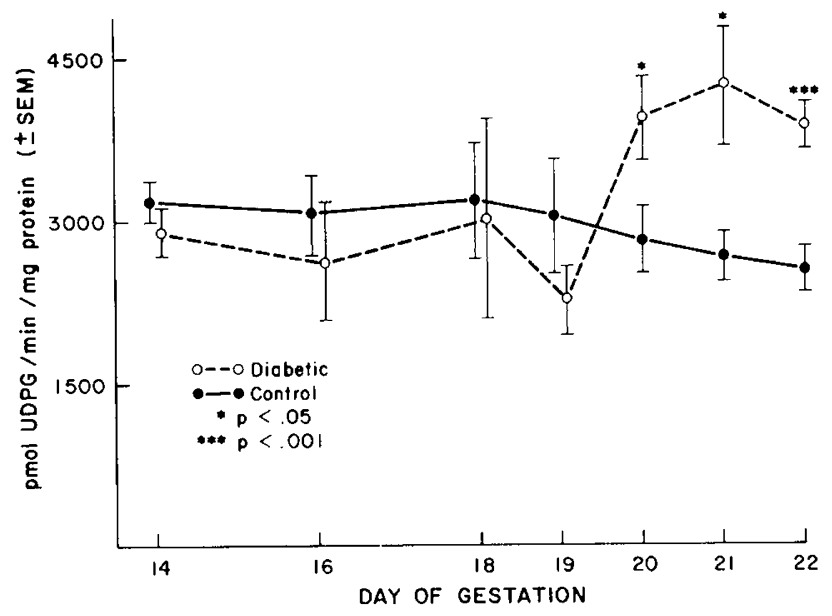

Fig. 4. Total $(A+B)$ placental glycogen synthase activity.

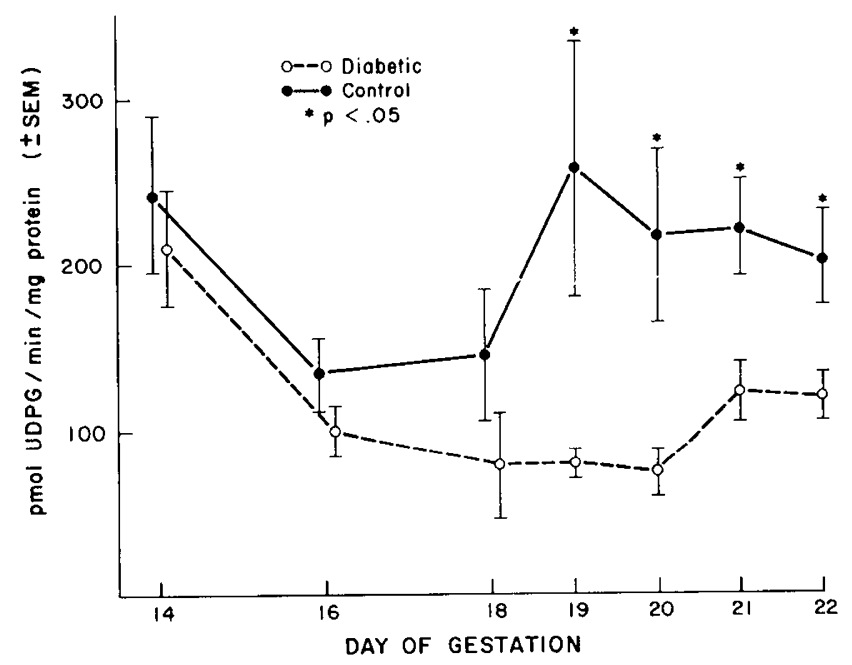

Fig. 5. Placental glycogen synthase A activity.

DNA concentration decreased in both diabetics and controls, and no differences were noted between age-matched placentas. No difference in protein concentration was noted between the two groups; thus, protein/DNA ratio increased with advancing gestational age in both, although for a given gestational age no differ-
Table 2. Placental weight ${ }^{2}$ ( $m g$ wet weight $\pm S$.E.)

\begin{tabular}{cllllc}
\hline Day & Control & $n^{2}$ & Diabetic & $n^{2}$ & $P$ \\
\hline 14 & $130 \pm 4$ & $(7)$ & $134 \pm 3$ & $(5)$ & $\mathrm{NS}^{3}$ \\
16 & $264 \pm 16$ & $(5)$ & $221 \pm 18$ & $(6)$ & $\mathrm{NS}^{3}$ \\
17 & $282 \pm 22$ & $(4)$ & & & \\
18 & $357 \pm 15$ & $(7)$ & $451 \pm 42$ & $(5)$ & $<0.05$ \\
19 & $412 \pm 11$ & $(12)$ & $643 \pm 44$ & $(7)$ & $<0.001$ \\
20 & $443 \pm 18$ & $(12)$ & $651 \pm 43$ & $(10)$ & $<0.001$ \\
21 & $479 \pm 17$ & $(13)$ & $679 \pm 51$ & $(11)$ & $<0.001$ \\
22 & $485 \pm 16$ & $(12)$ & $787 \pm 65$ & $(18)$ & $<0.001$ \\
\hline
\end{tabular}

' Results are expressed as $\mathrm{mg}$ wet weight \pm S.E.

${ }^{2} n$, Number of pregnancies with 6-8 placentas weighed per pregnancy.

${ }^{3} \mathrm{NS}$, not significant.

ence between diabetics and controls was noted. After day 16 a significant increase in DNA content/placenta became apparent in the diabetic placentas when compared to age-matched controls (Fig. 6). Furthermore, the total DNA in the diabetic placentas continued to increase until day 18-19 of gestation, whereas the placental DNA in the controls remained constant after day 16 The diabetic placentas apparently continue the process of DNA replication for 2-3 days after DNA synthesis is complete in the control group.

\section{DISCUSSION}

The importance of placental glycogen as a potential substrate and energy source for both placenta and fetus has long been recognized (2). The decreased concentration of placental glycogen as term approaches is a normal occurrence in the many species studied $(4,26,33)$, and is thought to result from increased glucose utilization and increasing metabolic rate as pregnancy progresses $(6,11)$.

Previous investigators have noted an increase in placental glycogen in both naturally occurring and experimentally induced diabetes mellitus $(1,9,13,16,17,30)$. Most of these studies focus on a single time early or late in gestation, and hence may not reflect the complete pathophysiology of this rapidly changing organ. The present study indicates that the increase in placental glycogen concentration is present as early as the 16th day of the rat gestation and continues to term.

Placental glycogen synthase A activity was significantly lower in diabetic placentas from day 19 through term, in agreement with prior studies with 20-day rat placentas (1) and late gestation human placentas (9). Total synthase activity was increased in the diabetic placentas for the final 3 days of gestation. The active/ total ratio was twice as high in the control placentas. Although the presence of increased levels of endogenous glucose-6-phosphate in the diabetics may have resulted in an apparent increase in the active (independent) synthase fraction in the synthase assay, the diabetic placentas nevertheless had decreased synthase A activity, suggesting that this difference may have been more pronounced if endogenous glucose-6-phosphate pools had been eliminated.

The concept of substrate regulation of glycogen metabolism has been extensively studied in the liver (19). Hyperglycemia can acutely increase glycogen concentration via its effects on regulatory enzymes. Glucose has been shown to increase synthase A levels by activating synthase phosphatase $(3,14,19)$. It also inhibits phosphorylase A activity by diminishing the enzyme's binding site affinity for glucose-1-phosphate, and directly decreases phosphorylase A levels by activating phosphorylase phosphatase (21). These effects are apparently independent of insulin $(3,14)$. Because the fetuses in our model are hyperglycemic but not hyperinsulinemic, it is possible that the decrease in phosphorylase A is mediated by the hyperglycemia per se.

Increasing glycogen concentration can result in non-hormonal regulatory feedback, with inhibition of synthase phosphatase and subsequent reduction of the active synthase fraction; this has been 
Table 3. Placental DNA and protein concentration ${ }^{1}$

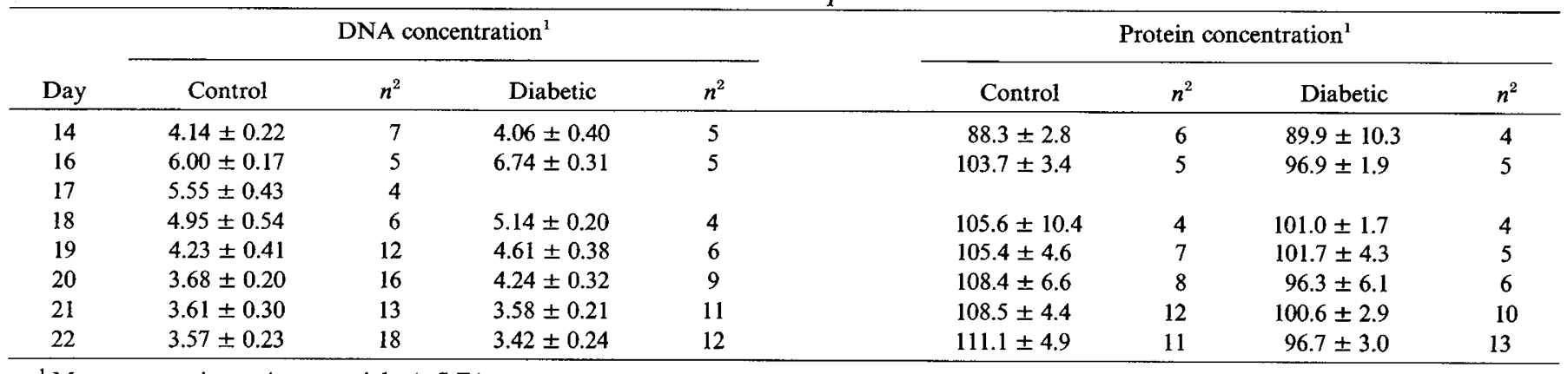

${ }^{1}$ Measurement in $\mathrm{mg} / \mathrm{g}$ wet weight $( \pm$ S.E.).

${ }^{2} n$, Number of pregnancies, with $2-3$ placentas used from each pregnancy.

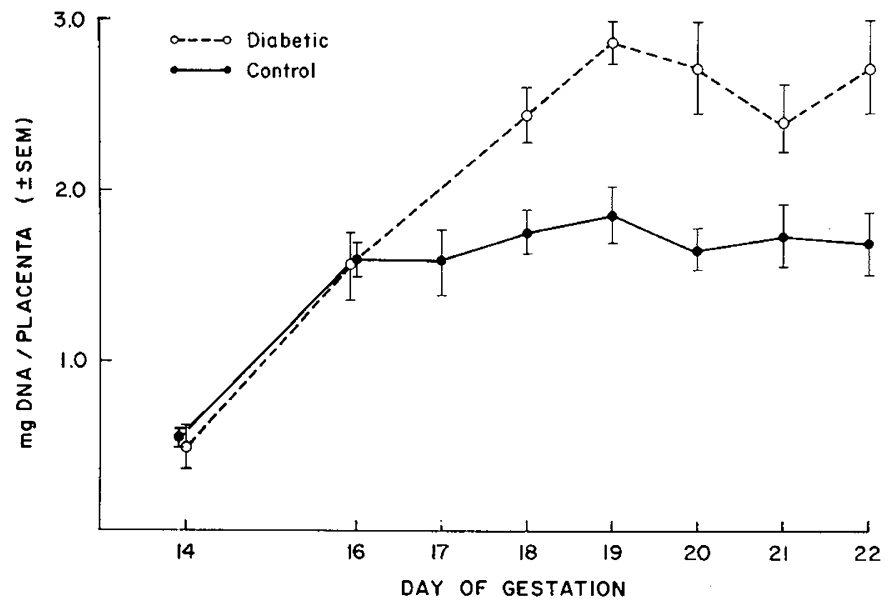

Fig. 6. Total DNA/placenta.

shown in rat liver and skeletal muscle $(5,18,32)$, as well as in human placenta (9). This regulatory effect becomes evident at glycogen levels of approximately $1-4 \mathrm{mg} / \mathrm{g}$ in rat skeletal muscle (5) and human placenta (9). This is consistent with our data showing that differences in synthase $A$ and active/total synthase ratio become evident only after day 18 , when control glycogen values fall below $40 \mu \mathrm{g} / \mathrm{mg}$ protein, or approximately $4 \mathrm{mg} / \mathrm{g}$ wet weight.

The developmental profile of phosphorylase activity in our experiments is at variance with previous reports in humans and streptozotocin diabetic rats. Abramovici et al. (1) noted slightly decreased activity of total phosphorylase in diabetic rats on day 20 , unlike our findings of an increase in total activity after day 16 . They did not measure the A fraction. Gabbe et al. (9) found increased total phosphorylase activity, but, unlike the present study, reported increased activity of the active fraction in their human diabetic placentas. Methodologic considerations may explain the differences between their study and the present work. Gabbe et al. (9) found an active/total phosphorylase ratio of approximately $50 \%$, in contrast to our finding of a ratio of less than $10 \%$. The pre-incubation step using adenylic acid deaminase to eliminate endogenous 5'AMP reduced the A fraction considerably. Hence, it is possible that they were measuring inactive as well as active phosphorylase in their A fraction.

Decreased phosphorylase $A$ activity in the diabetic placenta correlates with the increased glycogen concentration seen near term. This is in keeping with our previous finding (12) of a decrease in pulmonary phosphorylase A activity in the diabetic fetal lung at precisely that time late in pregnancy when a delay in pulmonary glycogen degradation occurred. Nevertheless, since diabetic placentas evidenced increased glycogen accumulation prior to the appearance of differences in enzyme activity, it is clear that enzyme changes cannot of themselves account for all the observed differences in glycogen concentration. Phosphorylase A activity may be rate-limiting near term when degradative processes predominate, whereas increased substrate availability and perhaps increased activity of intermediate forms of synthase $(22,29)$ may be more important earlier in gestation when synthesis is predominant.

Placental protein/DNA ratio increases during gestation in both diabetics and controls, but the protein/DNA ratio on any given day in gestation is the same for both groups, consistent with Winick and Noble's results with human diabetic and pre-diabetic placentas (35). It is important to emphasize, however, the differences between the streptozotocin diabetic rat and the human diabetic pregnancy. The streptozotocin diabetic pregnancy is characterized by placentomegaly, smaller fetal size, and lack of fetal hyperinsulinemia, so that comparison of data and extrapolation of conclusions to the human experience must be done with caution.

The placentomegaly in association with fetal growth retardation seen in this model may be the result of preferential substrate utilization by the placenta or, alternatively, by an impairment of placental transport. This requires further study. Certain morphologic characteristics of diabetic placentas have raised the question of a maturational delay or a functional dysmaturity, since the large villi and increased glycogen content seen in the diabetic state are usually seen at an earlier stage in gestation in normal pregnancies $(1,28)$. It can be speculated that the continuous hyperglycemia is a stimulus for continued placental growth at the expense of the initiation of maturation. Some support for this hypothesis may be found in the present study, where there is an indication that DNA synthesis in the diabetic placenta continues for an additional 2-3 days after control placentas have completed DNA synthesis (34). This ability to continue to grow may reflect a relative immaturity, or dysmaturity, of this organ, similar to the large but relatively immature lung and liver of the infant of the human diabetic pregnancy.

\section{REFERENCES AND NOTES}

1. Abramovici, A., Sporn, J., Prager, R., Shaltiel, A., Laron, Z., and Liban, E. Glycogen metabolism in the placenta of streptozotocin diabetic rats. Horm. Metab. Res., 10: 195 (1978).

2. Bernard, C.: De la matière glycogène considerée comme condition de développement de certains tissues chez la foetus avant l'apparition de la function glycogènique du foie. C. R. Acad. Sci., 48: 673 (1859).

3. Buschiazzo, H., Exton, J. H., and Park, C. R.: Effects of glucose on glycogen synthetase, phosphorylase, and glycogen deposition in the perfused rat liver. Proc. Nat. Acad. Sci., 65: 383 (197).

4. Corey, E. L.: Growth and glycogen content in the fetal liver and placenta. Am J. Physiol. 112: 263 (1955).

5. Danforth, W. H.: Glycogen synthetase activity in skeletal muscle. J. Biol. Chem., 240: $588(1965)$

6. Diamant, Y. Z. and Shafrir, E.: Enzymes of carbohydrate and lipid metabolism in the placenta and liver of pregnant rats. Biochim. Biophys. Acta, 279: 424 (1972).

7. Eisen, H. J., Goldfine, I. D., and Glinsmann, W. H.: Regulation of hepatic glycogen synthesis during fetal development: Roles of hydrocortisone, insulin and insulin receptors. Proc. Nat. Acad. Sci., 70: 3454 (1973).

8. Eriksson, V., Andersson, A., Effendic, S., Elde, R., and Hellerstrom, C.: Effects on the fetal and newborn rat with respect to birthweight, insulin concentration, and pancreatic contents of insulin, glycogen, and somatostatin. Acta Endocrinol., 94: 354 (1980).

9. Gabbe, S. G., Demers, L. M., Greep, R. O., and Villee, C. A.: Placental glycogen 
metabolism in diabetes mellitus. Diabetes, 21: 85 (1972).

10. Gabbe, S. G., Demers, L. M., Greep, R. O., and Villee, C. A.: The effects of hypoxia on placental glycogen metabolism. Am. J. Obstet. Gynecol, I14: 540 (1972).

11. Gennser, G., Lunquist, I., and Nilsson, E.: Carbohydrate content and glycogenolytic activity in human placenta and fetal heart and lung. Biol. Neonate, 21 148 (1972).

12. Gewolb, I. H., Barrett, C., Wilson, C. M., and Warshaw, J. B.: Delay in pulmonary glycogen degradation in fetuses of streptozotocin diabetic rats. pulmonary glycogen degradic Res., 16: 869 (1982).

13. Ginsburg, J. and Jeacock, M. K.: Some aspects of placental glycogen metabolism in human diabetes. J. Obstet. Gynaecol. Br. Common., 73: 452 (1966)

14. Glinsmann, W., Pauk, G., and Hern, E.: Control of rat liver glycogen synthesis and phosphorylase activity by glucose. Biochem. Biophys. Res. Commun., 39 . 774 (1970).

15. Golob, E. K Rishi, S, Becker, K. L., Moore, C., and Shah, N.: Effect of streptozotocin induced diabetes mellitus on pancreatic insulin content of the fetus. Diabetes, 19: 610 (1970).

16. Hagerman, D. D.: Metabolism of tissues from pregnant, diabetic rats in vitro. Endocrinology, 70: 88 (1962).

17. Heijkenskold, F. and Genzell, C. A.: Glycogen content in the placenta of diabetic mothers. Acta Paediatr., 46: 74 (1957).

18. Hers, H. G., DeWulf, H., Stalmans, W., and Van den Berghe, G.: The control of glycogen metabolism in the liver. Adv. Enzyme Regul., 8: 171 (1970).

19. Hers, H. G.: The control of glycogen metabolism in the liver. Annu. Rev. Biochem., 45: 167 (1976).

20. Hill, B. T. and Whatley, S.: A simple rapid microassay for DNA. FEBS Lett. 56 (1): 20 (1975)

21. Holmes, P. A. and Mansour, T. E.: Glucose as a regulator of glycogen phosphorylase in rat diaphragm I. The effect of glucose and related compounds on phosphorylase and glycogen levels. Biochim. Biophys. Acta, 156: 266 (1968)

22 Kaslow, H. R., Eichner, R. D., and Mayer, S. E.: Interconversion between multiple glucose-6-phosphate-dependent forms of glycogen synthase in intact adipose tissue. J. Biol. Chem., 254: 4676 (1979)

23. Lowry, O. H., Rosebrough, N. J., Farr, A. L., and Randall, R. J.: Protein measurement with the folin phenol reagent. J. Biol. Chem., 193: 265 (1951).

Copyright $(\odot) 1983$ International Pediatric Research Foundation, Inc $0031-3998 / 83 / 1707-0587 \$ 02.00 / 0$
24. Lowry, O. H. and Passoneau, J. V.: A Flexible System of Enzyme Analysis. pp. 169-173 (Academic Press, New York, 1972).

25. Maniscalco, W. M., Wilson, C. M., Gross, I., Gobran, L., Rooney, S. A., and Warshaw, J. B.: Development of glycogen and phospholipid metabolism in fetal and newborn rat lung. Biochim. Biophys. Acta, 530: 333 (1978).

26. Padykula, H. A and Richardson, D.: A correlated histochemical and biochemical study of glycogen storage in the rat placenta. Am. J. Anat., 112: 215 (1963)

27. Pitkin, R. M. and Van Orden, D. E.: Fetal effects of maternal streptozotocin diabetes. Endocrinology, 94: 1247 (1974).

. Sci., 11: 623 (1975).

29. Saugmann, P.: Glycogen synthase "R": The occurrence and significance of previously unknown form of GS, found in metabolically active human leucocytes. Biochem. Biophys. Res. Commun., 74: 1511 (1977).

30. Sybulski, S. and Maughan, G. B.: Use of streptozotocin as a diabetic agent in pregnant rats. Endocrinology, 89: 1537 (1971).

31. Tyden, $\mathrm{O}$ Berne, $\mathrm{C}$, and Eriksson, $\mathrm{V}$ : Lung maturation in fetuses of diabetic rats. Pediatr. Res., 14: 1192 (1980).

32. Villar-Palasi, C. and Larner, J.: Feedback control of glycogen metabolism in muscle. Fed. Prox., 25: 583 (1966)

33. Villee $C$. A. Biochemical evidence of aging in the placenta. In: Wolstenholme G. E. W. and Millar, E. C. P., Eds.: CIBA Foundation Colloquia on Aging. Vol 2, pp. 129-144 (Churchill Co., London, 1956).

34. Winick, $M$. and Noble, A.: Quantitative changes in ribonuceic acids and protein during normal growth of rat placenta. Nature, 212: 34 (1966).

35. Winick, M., and Noble, A.: Cellular growth in human placenta. 11. Diabetes Mellitus. J. Pediatr., 71: 216 (1967).

36. The present address of Dr. Ira Gewolb is the Department of Pediatrics, Albert Einstein School of Medicine, Bronx, New York 10461.

37. Requests for reprints should be sent to Dr. Joseph Warshaw. Department of Pediatrics, University of Texas Health Science Center at Dallas, 5323 Harry Hines Boulevard, Dallas, Texas 75235 .

38. This work was supported by USPHS Grant HL-30119 and Training Grant HD 07094 at Yale University School of Medicine, New Haven, CT.

39. Received for publication June 3,1982

40. Accepted for publication October 15. 1982

Printed in U.S.A. 